Article

\title{
Effective Exploitation Potential of Shale Gas from Lower Cambrian Niutitang Formation, Northwestern Hunan, China
}

\author{
Han Cao ${ }^{1,2,3}$, Tianyi Wang ${ }^{1,2}$, Ting Bao ${ }^{2,4, *}$, Pinghe Sun $1,2,3, * \mathbb{D}$, Zheng Zhang ${ }^{1,2}$ and \\ Jingjing $\mathrm{Wu}^{5}$ \\ 1 Schools of Geosciences and Info-Physics, Central South University, Changsha 410083, China; \\ hancao@csu.edu.cn (H.C.); wangty@csu.edu.cn (T.W.); 175011077@csu.edu.cn (Z.Z.) \\ 2 Key Laboratory of Metallogenic Prediction of Nonferrous Metals and Geological Environment \\ Monitoring (Ministry of Education), Central South University, Changsha 410083, China \\ 3 Key Laboratory of Oil and Gas Reservoir Geology and Exploitation, Southwest Petroleum University, \\ Chengdu 610500, China \\ 4 Department of Civil and Environmental Engineering, Michigan Technological University, \\ 1400 Townsend Drive, Houghton, MI 49931, USA \\ 5 College of Civil Engineering, Hunan University of Technology, Zhuzhou 412007, China; \\ wujingjing0408@csu.edu.cn \\ * Correspondence: tbao@mtu.edu (T.B.); pinghesun@csu.edu.cn (P.S.)
}

Received: 24 October 2018; Accepted: 29 November 2018; Published: 2 December 2018

check for updates

\begin{abstract}
The marine shale in the Lower Cambrian Niutitang Formation is the dominant shale-gas reservoir in northwestern Hunan, which accounts for more than $70 \%$ of unconventional energy in Hunan province. Accurately evaluating the shale-gas exploitation potential is a key to determining whether commercial exploitation standards can be met. In the literature, most existing studies have focused on evaluating the shale-gas exploitation potential based on either accumulation conditions or the shale fracability, which will lead to a gap between the real production and proven gas reserves due to the characteristics of the shale's low permeability and low porosity. Therefore, further studies are needed to evaluate the effective shale-gas exploitation potential. To address this need, the outcrop shale samples in the Niutitang Formation were collected from the target regions, and the geological characteristics, mechanics behavior, and microstructure performance were discussed via both field data and laboratory tests. The results revealed that the shale-gas exploitation potential in the Niutitang Formation was indicated to be comparable to that of five validated shale-gas exploitation regions in the United States. To further illustrate the effective shale-gas exploitation potential, this study suggested using a comprehensive evaluation framework for this purpose, in which both accumulation condition and the shale fracability are simultaneously considered. Therefore, the shale gas reservoir in the Niutitang Formation has highly effective shale-gas exploitation potential by considering both the accumulation conditions and the shale fracability.
\end{abstract}

Keywords: marine shale; Niutitang Formation of Lower Cambrian; effective exploitation potential; accumulation characteristics; shale fracability

\section{Introduction}

Shale gas stored in organic-rich shales is an important unconventional energy source [1,2]. In recent years, the shale gas exploitation is blooming worldwide. In particular, the United States has entered the large-scale commercial exploitation of shale gas. According to Annual Energy Outlook 2018 Early Release [3], it is estimated that 39\% of U.S. energy production by 2050 will come from 
natural gas, and the shale gas production could be comparable to the total U.S. natural gas production. It is also forecast that the shale gas production will keep increasing because of the large size of the associated shale gas resources [3]. For the commercial exploitation of shale gas, the key to increasing its production is to determine the exploitation potential of shale gas reservoirs. This exploitation potential is determined by both natural geological conditions and exploitation technologies [4]. Due to the low permeability and low porosity of shale gas reservoirs [5], both accumulation conditions and fracturing technologies need to be considered to comprehensively to predict the effective exploitation potential of the production areas, including geochemical characteristics, mechanical characteristics, microscopic characteristics, and shale fracability.

Many studies [4-8] have been carried out on shale gas from the aspect of definitions, characteristics, accumulation mechanisms, occurrence modes, favorable area selection indices, and resource evaluations. According to the guideline for exploring shale gas in North America [9], the target area for the shale gas exploration should be chosen based on the geological conditions and brittleness of reservoirs. For example, the target area should be a mature shale distribution area with a total organic carbon content (TOC) $>2 \%$ and rich silicas, as such an area is favorable to develop fracture networks for accumulating shale gas [10]. The great success in the exploration and development of the Barnett shale gas field in Fort Worth Basin is attributed to favorable conditions, such as high gas content (mainly free gas) and good fracability $[4,11]$. The natural fracture network system in shale can also greatly increase the matrix permeability [6]. Based on that, the natural gas, which is adsorbed on the surface of clay and organic matter particles in the shale gas matrix pores, is discharged as much as possible. This gas discharge makes the shale gas field finally successful for commercial exploitation (such as Antrim and Marcellus shale gas) [12].

Shale gas exploration drilling is already underway in China. Most studies have explored the Sichuan Basin [13-15] and Yangtze Platform areas $[16,17]$ to evaluate the potential of shale gas for commercial exploitation by discussing the optimization of the indicator system, the determination of parameters standard, and the selection of methods. He et al. [13] and Zhang et al. [14] studied the shale gas enrichment mechanism and reservoir capacity by analyzing the micropore characteristics of the Wufeng-Longmaxi Formation shale in the Sichuan Basin. Yong et al. [14] used the structural analysis method to combine the burial depth and fault length of the Longmaxi Formation in the southeastern Sichuan Basin to evaluate the shale gas reservoir conditions and favorable exploration targets. Li et al. [16] and Wang et al. [17] systematically analyzed the shale gas source conditions, reservoir conditions, and gas-bearing properties in northwest Jiangxi, providing a basis for further gas exploitation and development.

The shale gas exploitation in Hunan, China is still in an infancy stage compared with those in the Sichuan Basin. In fact, the shale in the Niutitang Formation has better accumulation conditions and thus can be considered as the target layer for shale gas exploitation in northwestern Hunan when compared with the Lower Silurian Longmaxi Formation shale in the same region [18]. The analysis of the geological data $[19,20]$ showed that the Changye-1 well has good gas-bearing properties and also found that the shales of 1100-1250 m underneath the surface are the most favorable interval for shale gas development with a high quality. In addition, the existing studies adopted thin section observation, organic petrological analysis, SEM (scanning electron microscope), and isothermal adsorption experiments to study the formation conditions of the Niutitang Formation in northwestern Hunan and the distribution of favorable areas [21,22]. Xiao et al. [23] evaluated the reservoir forming conditions and exploration potential of the Niutitang Formation shale in northwestern Hunan based on sedimentology, geochemistry, mineralization, and controlling factors. However, all of the above studies overlooked the reservoir fracability, which in fact is of great significance for optimizing fracturing well sections and predicting economic benefits. There is no unified standard for fracability evaluation of reservoirs across the world. Brittleness is an important mechanical parameter for optimizing fractured wells and predicting economic benefits [24]. Wan et al. [25] quantitatively analyzed the brittleness of the reservoir based on the shale mineral composition. However, quantitative evaluations based 
on a single factor, such as mineral composition or rock mechanics, fail to reflect the comprehensive characteristics of the fracturing process [26,27]. Jin et al. [28] evaluated the fracability by integrating the brittleness index and other parameters, such as fracture toughness and strain energy release rate. Other studies $[29,30]$ adopted the contents of brittle minerals to calculate the fracability index. Enderlin et al. [31] concluded that the fracability depends on not only the material brittleness but also other factors, e.g., diagenesis, ductility, natural fractures, tensile strength, and so on. However, these evaluations of fracability did not consider the effects of the factors upon accumulation conditions.

Accurately evaluating the shale-gas exploitation potential is a key to determining whether commercial exploitation standards can be met. However, as introduced above, most studies in the literature have focused on evaluating the shale-gas exploitation potential separately based on either accumulation conditions or the shale fracability. This separate evaluation will result in "rough" shale-gas exploitation potential rather than the "effective" potential, leading to a difference between proven gas reserves and gas production. This is because not all shale gas can be extracted from the reservoir with low permeability without conducting hydraulic fracturing. However, the fracability is a key to determining the sweet spot for hydraulic fracturing to update the original accumulation conditions by reforming the formation with low permeability. Therefore, it is urgently needed to investigate the "effective" shale-gas exploitation potential by taking a full consideration with accumulation conditions and shale fracability.

Motivated by this knowledge gap, this study investigates the effective exploitation potential of shale gas, in which both accumulation conditions and the shale fracability are considered. To achieve this, the exploitation potential of marine shale in the Niutitang Formation in northwestern Hunan was discussed via both field data and laboratory tests. The geological setting of northwestern Hunan was introduced first. Then, a field study and a series of laboratory tests were conducted to investigate geological characteristics and fracability behaviors for the following discussions. After that, the experimental results were presented. Finally, in-depth discussions considering both accumulation conditions and the shale fracability were made to evaluate effective shale gas exploitation potential in the Niutitang Formation.

\section{Geological Setting}

\subsection{Overview}

Due to the highly abundant and widely distributed outcrop shales, the Niutitang Formation in northwestern Hunan is the target formation for marine shale gas exploitation. The fold erosion and denudation mountain areas in northwestern Hunan are distributed in Longshan, Yongshun, Baojing, Huayuan, Zhangjiajie, and Changde (as shown in Figure 1), with an altitude of 800-1200 m.

The geotectonics shows that the research region is located in the Jiangnan tectonic activation belt in the middle of the Yangtze block. The western Hunan area has undergone multi-phase tectonic movements. Under the background of the overall settlement, these tectonic movements have successively included the formation, development, atrophy, and disappearance of the Craton Basin and the development of the foreland basin, forming a complete tectonic evolution cycle. In the Early Cambrian and Late Ordovician-Early Silurian ages, extensive marine transgression occurred in the middle of Yangtze area, and two sets of important source rocks were deposited. Outcrops and drilling data showed that the Niutitang Formation is generally in the deep-sea basin environment, and it is characterized by a large number of phosphorus-containing and invasive pyrite nodules. It is also sandwiched by an enriched layer of sedimentary barite, a thin layer of powdered phosphorite rock, a developed micro-erosion surface, and graded bedding. 


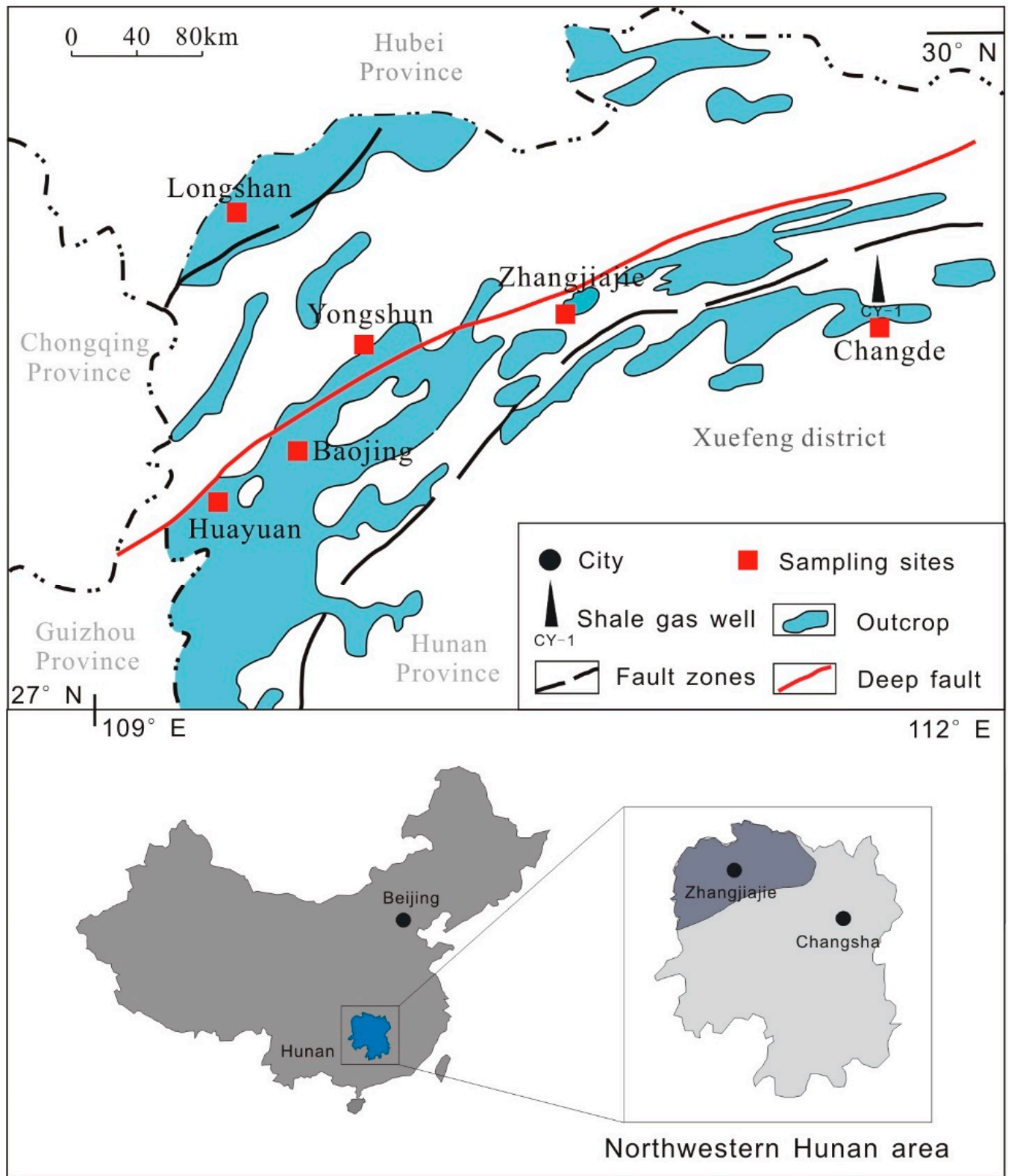

Figure 1. The map of regional structure and outcrop distribution of the marine shale in northwestern Hunan. The coordinates of the shale gas well (CY-1) is $(111.725449,29.186193)$.

\subsection{Shale-Distribution Characteristics}

According to the outcrop and profile, a marine shale set with a large thickness is developed in the lower part of the Niutitang Formation in northwestern Hunan, and the whole marine shale distribution is relatively stable. Taking the representative sedimentary and stratigraphic section at well CY-1 as an example (as shown in Figure 2), the stratigraphic situation is indicated in the study area. CY-1 is located in the Taiyang mountain anticline of Changde, Hunan Province, with a geographic coordinate of $(111.725449,29.186193)$. Due to the tectonic activity, the shale layers are mostly inclined, and the vertical thickness of the shale differs with the changing inclined angles. The thickness distribution is obviously controlled by the sedimentary facies, indicating that the thickness of the marine shale is gradually reduced from the deep-water shelf facies to the slope facies [23]. Based on the drilling data and previous oil and gas data in this area, it is estimated that the effective thickness of marine shale in this region ranges from 70 to $170 \mathrm{~m}$, and the overall trend of thickness increases from northwest to southeast. 


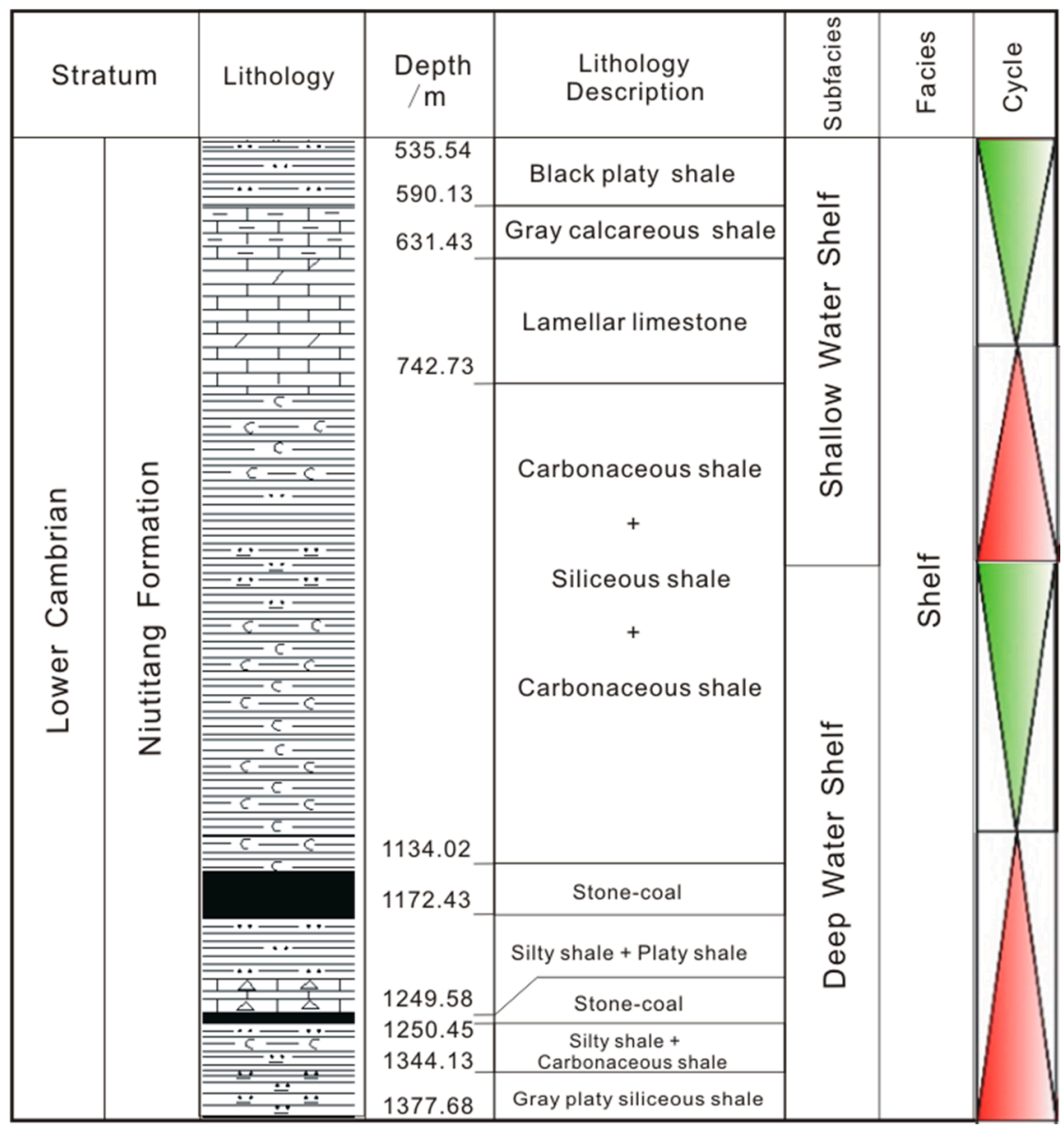

Figure 2. Niutitang Formation sedimentary and stratigraphic section at well CY-1.

\section{Materials and Methods}

A comprehensive investigation on the effective exploitation potential of marine shale (typical carbonaceous shale, siliceous shale) in northwestern Hunan was conducted, including data collection of an exploratory well, outcrop observation, sample collection, and laboratory tests. Figure 3 shows the typical shale outcrops at Huayuan, Zhangjiajie, and Changde in the target regions. To consider both accumulation conditions and fracability, laboratory tests were conducted to analyze geochemical, organic petrology, rock mechanics, and microstructure. More specifically, accumulation conditions were analyzed based on organic matter types and contents, the maceral of organic kerogen, thermal maturity, and microscopic pore characteristics. The fracability analysis includes X-RD (X-Ray Diffraction) mineral component tests, uniaxial compression tests, observation of natural fractures, and isothermal adsorption tests. The brittleness index of shale is determined by the formula of brittleness coefficient of Rickman [32]:

$$
\begin{gathered}
Y M_{-} B R I T=\left(\left(Y M S \_C-Y M_{\text {min }}\right) /\left(Y M_{\text {max }}-Y M_{\text {min }}\right)\right) \times 100 \\
P R \_B R I T=\left(\left(P R \_C-P R\right) /\left(P R_{\text {min }}-P R_{\text {max }}\right) \times 100\right. \\
B R I T=\left(Y M \_B R I T+P R \_B R I T\right) / 2
\end{gathered}
$$

where BRIT = brittleness coefficient, $Y M S \_C=$ composite determination of Young's modulus (GPa), and PR_C = composite determination of Poisson's ratio.

A helium porosity meter was used to analyze the porosity. The apertures and specific surface areas of the rock samples were determined using a low-temperature nitrogen adsorption method. 
Three methods, including the Brunauer-Emmett-Teller (BET) of the specific surface area, isothermal adsorption, and Density Functional Theory (DFT), were used to analyze the adsorption capacity and microstructure.

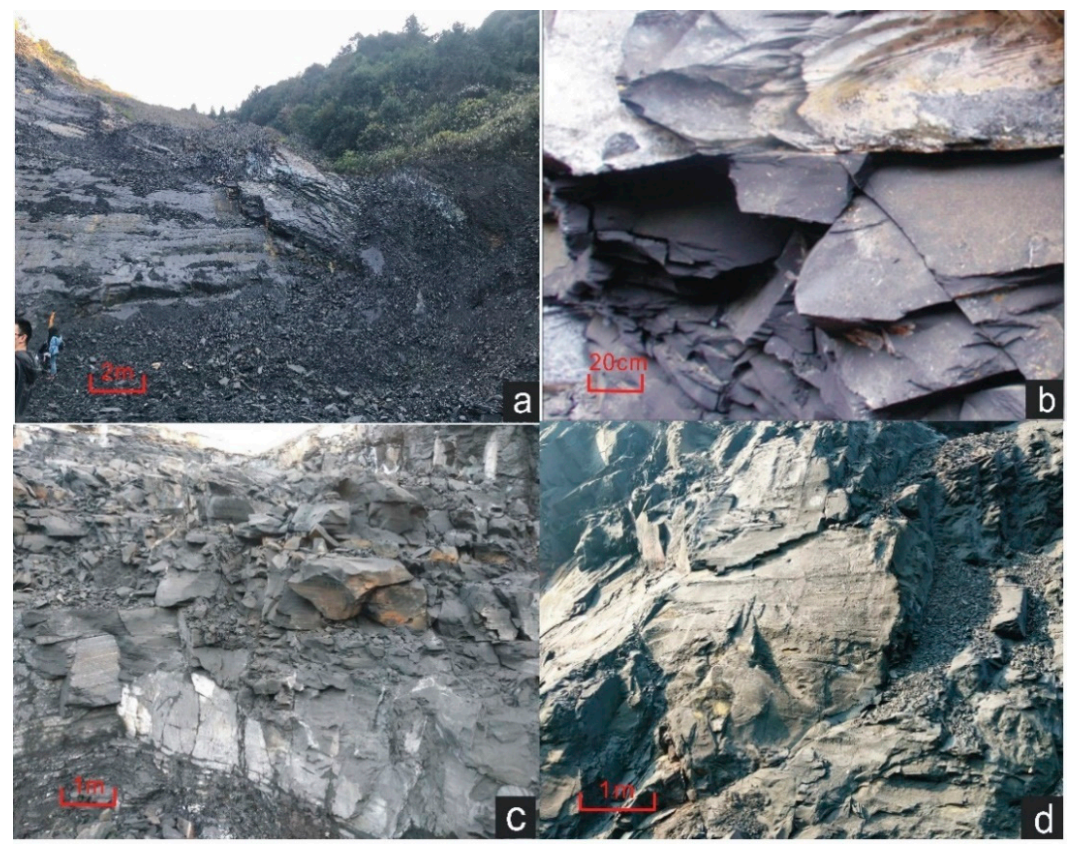

Figure 3. Niutitang Formation shale in northwestern Hunan: (a) outcrop at Huayuan (109.467028, 28.556155), sample 4\#; (b) outcrop at Zhangiiajie (110.555208, 29.075137), sample 5\#; (c) outcrop at Changde $(111.686879,29.192547)$, samples 6\#-8\#; (d) another outcrop at Changde (111.698325, 29.191317), samples 9\#-11\#.

\section{Experimental Results}

\subsection{Mineral Composition}

Figure 4 shows mineral components of the marine shale obtained by the $\mathrm{X}$-RD testing. Table 1 shows the mineral composition of outcrop shale in the target area. The shale mainly consists of quartz, feldspar, pyrite, and a small amount of barite, calcite, and mica. Clay minerals in the samples range from $7.36 \%$ to $36.2 \%$, brittle minerals from $34.1 \%$ to $76.2 \%$, and the pyrite from $8.1 \%$ to $27.3 \%$.

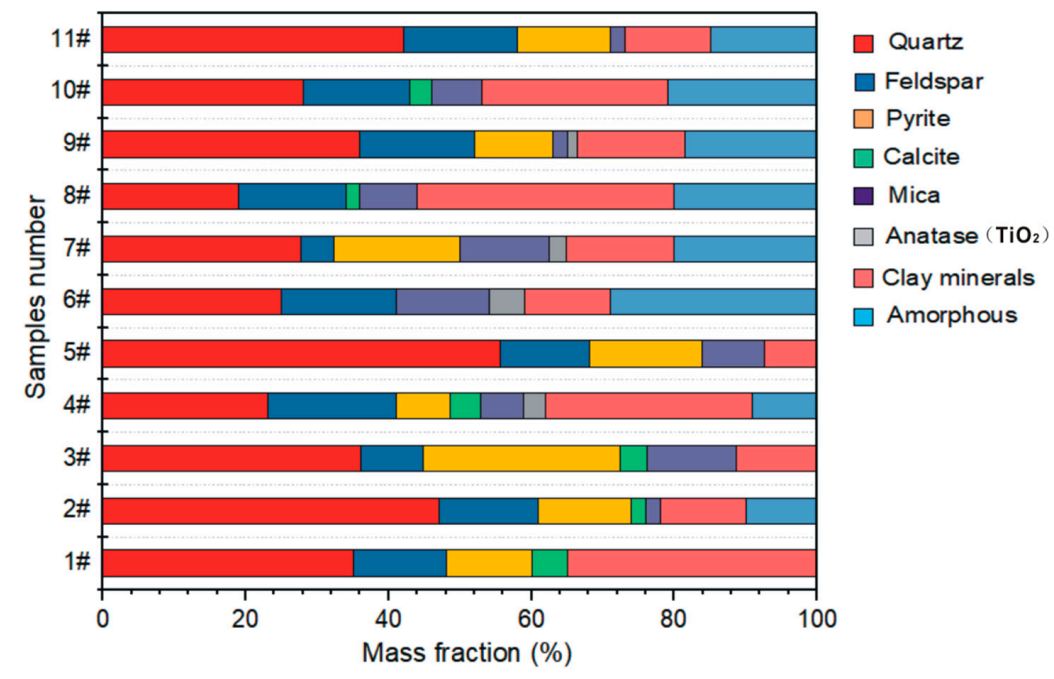

Figure 4. The percentage content of minerals from outcrop shales. 
Table 1. The mineral composition of outcrop shale in the target area.

\begin{tabular}{|c|c|c|c|c|c|c|c|c|c|}
\hline $\begin{array}{c}\text { Location } \\
\text { (Coordinates) }\end{array}$ & $\begin{array}{l}\text { Samples } \\
\text { Number }\end{array}$ & $\begin{array}{c}\text { Quartz } \\
(\%)\end{array}$ & $\begin{array}{c}\text { Feldspar } \\
(\%)\end{array}$ & $\begin{array}{l}\text { Pyrite } \\
(\%)\end{array}$ & $\begin{array}{l}\text { Calcite } \\
(\%)\end{array}$ & $\begin{array}{l}\text { Mica } \\
(\% 0)\end{array}$ & $\begin{array}{c}\text { Anatase } \\
(\%)\end{array}$ & $\begin{array}{c}\text { Clay } \\
\text { Mineral (\%) }\end{array}$ & $\begin{array}{c}\text { Amorphous } \\
(\%)\end{array}$ \\
\hline $\begin{array}{c}\text { Longshan } \\
(109.401417, \\
29.43082)\end{array}$ & $1 \#$ & 35 & 13 & 12 & 5 & 0 & 0 & 35 & 0 \\
\hline $\begin{array}{c}\text { Yongshun } \\
(109.892638, \\
28.994641)\end{array}$ & $2 \#$ & 47 & 14 & 13 & 2 & 2 & 0 & 12 & 10 \\
\hline $\begin{array}{c}\text { Baojing } \\
(109.700429 \\
28.712333)\end{array}$ & 3\# & 36 & 9 & 27 & 4 & 13 & 0 & 11 & 0 \\
\hline $\begin{array}{c}\text { Huayuan } \\
(109.467028 \\
28.556155)\end{array}$ & $4 \#$ & 23 & 18 & 8 & 5 & 6 & 3 & 29 & 8 \\
\hline $\begin{array}{c}\text { Zhangjiajie } \\
(110.555208, \\
29.075137)\end{array}$ & $5 \#$ & 56 & 13 & 16 & 0 & 8 & 0 & 7 & 0 \\
\hline \multirow{6}{*}{$\begin{array}{c}\text { Changde } \\
(111.686879, \\
29.192547)\end{array}$} & 6\# & 25 & 16 & 0 & 0 & 13 & 5 & 12 & 29 \\
\hline & 7\# & 28 & 15 & 0 & 3 & 7 & 0 & 26 & 21 \\
\hline & 8\# & 19 & 15 & 0 & 2 & 8 & 0 & 36 & 20 \\
\hline & $9 \#$ & 36 & 16 & 11 & 0 & 2 & 2 & 15 & 18 \\
\hline & $10 \#$ & 27 & 5 & 18 & 0 & 13 & 2 & 15 & 20 \\
\hline & $11 \#$ & 42 & 16 & 13 & 0 & 2 & 0 & 12 & 15 \\
\hline
\end{tabular}

\subsection{Organic Matter Characteristics}

To obtain the organic petrology of the shales, the outcrop shale samples collected from target sites in northwestern Hunan were analyzed. It is seen in Figure 5 that the total organic carbon content (TOC) ranges from $2.60 \%$ to $4.10 \%$, and the thermal maturity (Ro) ranges from $2.70 \%$ to $3.60 \%$.

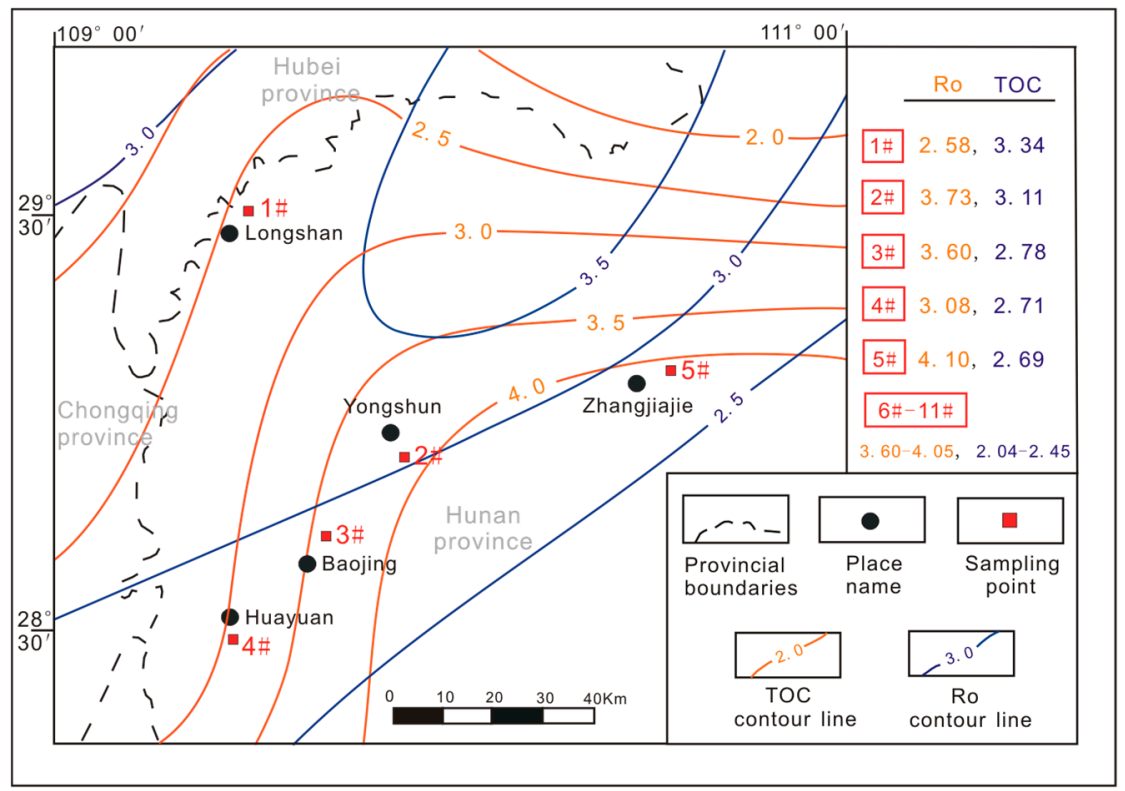

Figure 5. TOC (total organic carbon) and Ro (thermal maturity) distribution contour maps of Niutitang Formation shales in northwestern Hunan.

Based on the exploration of shale gas basins in North America, the kerogen in gas-producing shale is dominated by Type I and Type II [4,33,34]. However, due to the different sources and chemical composition of the microscopic components in different kerogen, the hydrocarbon generation characteristics are obviously different. Therefore, it is of great significance to study the maceral composition of kerogen. 
The majority of the sapropelite and vitrinite compositions are over $90 \%$ and the carbon isotope of kerogen ranges from $-30.23 \%$ to $-34.29 \%$. In our study, taking the kerogen (Type I) macerals (as shown in Table 2) of 3\#, 5\#, and 9\# shale samples as examples, the samples were collected from Baojing, Zhangjiajie, and Changde, respectively.

Table 2. Maceral composition of kerogen of the Niutitang Formation shales in northwestern Hunan.

\begin{tabular}{ccccccc}
\hline $\begin{array}{c}\text { Sample } \\
\text { Number }\end{array}$ & $\begin{array}{c}\text { Sapropelite and } \\
\text { Vitrinite (\%) }\end{array}$ & Exinite (\%) & $\begin{array}{c}\text { Inertinite } \\
\mathbf{( \% )}\end{array}$ & Type Index & $\boldsymbol{\delta}^{\mathbf{1 3}} \mathbf{C}(\boldsymbol{\%})$ & $\begin{array}{c}\text { Organic } \\
\text { Matter Type }\end{array}$ \\
\hline $3 \#$ & 92.0 & 8.0 & 0 & 86.0 & -32.92 & $\mathrm{I}$ \\
$5 \#$ & 96.6 & 0.7 & 2.7 & 93.2 & -32.28 & $\mathrm{I}$ \\
$9 \#$ & 95.3 & 4.3 & 0.3 & 91.8 & -30.57 & $\mathrm{I}$ \\
\hline
\end{tabular}

\subsection{Mechanical Parameters}

In this study, the uniaxial compression test and tensile test of shales were carried out by the rock universal testing machine and Brazilian splitting instrument. Table 3 shows the test results according to the stress-strain relationship. The uniaxial compressive strength (UCS) of the Niutitang Formation shale ranges from $6 \mathrm{MPa}$ to $65 \mathrm{MPa}$, the Young's modulus ranges from $1.25 \mathrm{GPa}$ to $31.36 \mathrm{GPa}$, and the Poisson's ratio ranges from 0.15 to 0.29 . The tensile strength ranges from 1.9MPa to $14.1 \mathrm{MPa}$.

Table 3. The mechanical parameters of marine shales in Niutitang Formation.

\begin{tabular}{ccccc}
\hline Sample Number & $\begin{array}{c}\text { Uniaxial } \\
\text { Compressive } \\
\text { Strength (MPa) }\end{array}$ & $\begin{array}{c}\text { Young's Modulus } \\
\text { (GPa) }\end{array}$ & Poisson's Ratio & $\begin{array}{c}\text { Tensile Strength } \\
\text { (MPa) }\end{array}$ \\
\hline $1 \#$ & 40 & 27.54 & 0.20 & 6.3 \\
$2 \#$ & 44 & 30.28 & 0.17 & 13.7 \\
$3 \#$ & 37 & 25.43 & 0.21 & 7.4 \\
$4 \#$ & 36 & 27.11 & 0.24 & 5.6 \\
$5 \#$ & 65 & 31.36 & 0.20 & 14.1 \\
$6 \#$ & 8 & 1.37 & 0.23 & 2.1 \\
$7 \#$ & 6 & 1.25 & 0.24 & 4.9 \\
$8 \#$ & 17 & 3.86 & 0.19 & 6.2 \\
$9 \#$ & 25 & 14.15 & 0.29 & 8.9 \\
$10 \#$ & 30 & 21.33 & 0.16 & 12.5 \\
$11 \#$ & 42 & 25.60 & 0.15 & \\
\hline
\end{tabular}

\subsection{Fractures Observation}

The development of natural fractures at the section of shale samples was observed to analyze the fracability and permeability of the shale reservoir. Obvious natural fractures can be found in carbonaceous shale and Quartz veins in siliceous shale. The observation of shale Morphology showed that in carbonaceous shale, fractures were developed with few branches and long length, and non-structural shrinkage fractures. Filling strip-like dissolution pores range from $0.5 \mathrm{~mm}$ to $1 \mathrm{~mm}$. However, in siliceous shale, the fractures were developed to shear fractures and tensile shear fractures with conjugate $\mathrm{X}$ type quartz filling. Details of the fracture observations will be discussed later in Section 5.2.3.

\subsection{Microstructure of Shales}

For low-porosity and low-permeability shale reservoirs, the porosity is a sensitive factor affecting the hydraulic fracturing [35], which is closely related to the shale fracture, development, and filling degree of the pore. The porosity of the shale in northwestern Hunan ranges from $3.24 \%$ to $7.47 \%$, with an average value of $5.87 \%$. 
According to the classification of the suction/desorption curve of Brunauer, the shale adsorption curve of the shale in northwestern Hunan is an anti-S-shaped, which is a type II adsorption isotherm. The curves of desorption versus relative pressure $\left(P / P_{0}\right.$ : the ratio of the actual pressure to the saturated vapor) can be roughly classified into three types, as shown in Figure 6. The first type (Sample 1\#) is that when the relative pressure is about 0.7 , where the desorption curve shows a significant inflection point (Figure 6a). The absorption/desorption curve has a large separation. Such shale pores are dominated by regular open-end cylindrical holes and narrow parallel plate holes. The second type (Sample 10\#) is that where the desorption curve first falls gently, and suddenly drops when the relative pressure is 0.5 (Figure $6 \mathrm{~b}$ ). Such a curve represents a slit capillary formed by parallel walls. This may be related to flaky clay particles in shale [36]. The third type (Sample 5\#) is that where the inflection point of the desorption curve is not obvious, and the absorption and desorption curves are approximately parallel (Figure 6c). Such shale pores are dominated by closed cylindrical holes, parallel plate holes, and pointed-shaped holes closed at one end. The specific surface area measured by the BET (Brunauer-Emmett-Teller) method ranges from $3.328 \mathrm{~m}^{2} / \mathrm{g}$ to $12.517 \mathrm{~m}^{2} / \mathrm{g}$, with an average value of $8.286 \mathrm{~m}^{2} / \mathrm{g}$. The average pore size ranges from $3.02 \mathrm{~nm}$ to $14.24 \mathrm{~nm}$, with an average value of $6.48 \mathrm{~nm}$.

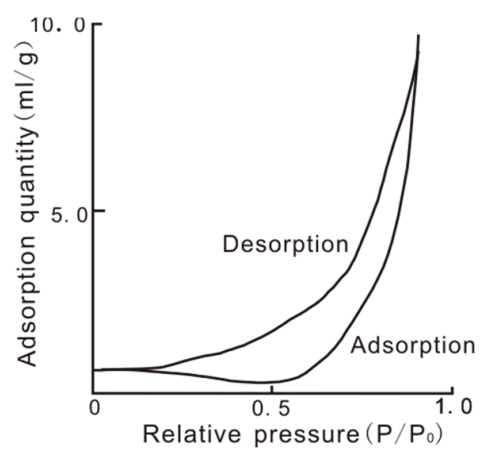

(a)

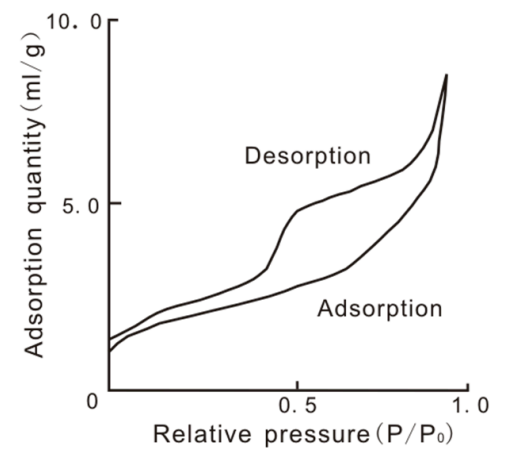

(b)

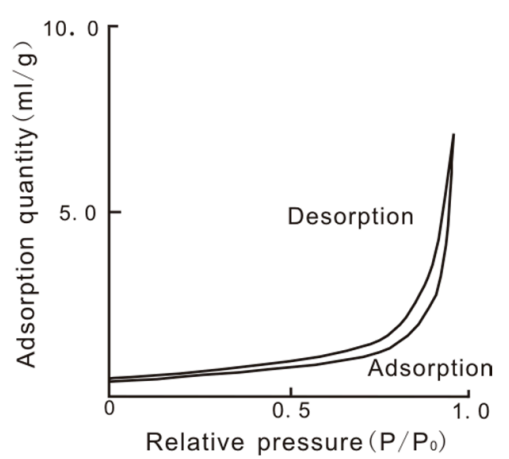

(c)

Figure 6. Three types adsorption-desorption curves of Niutitang Formation marine shales in northwestern Hunan. (a) Sample 1\#; (b) Sample 10\#; (c) Sample 5\#.

\section{Discussion}

\subsection{Accumulation Conditions}

\subsubsection{Adsorption Capacity}

The adsorption capability of shale significantly affects the evaluation and exploitation of shale gas resources. The abundant nanopores in clay minerals of the shale reservoir provide an effective adsorption space for methane. For montmorillonite especially, interlayer pores of $1 \mathrm{~nm}$ to $2 \mathrm{~nm}$ greatly affect the adsorption capacity of methane [37]. The clay mineral of the Niutitang Formation shale in northwestern Hunan ranges from $11.58 \%$ to $35.99 \%$, which is mainly composed of montmorillonite, illite, kaolinite, and mixed minerals. In addition, the pyrite in the siliceous shale ranges from $8.1 \%$ to $27.3 \%$, which is one of the key factors affecting shale adsorption capacity. The formation of pyrite is related to the formation of organic acids during the evolution of organic matter [38]. It is generally symbiotic with organic matter, and its content is positively correlated with the degree of organic matter enrichment.

Organic nanopores are one of the most widely available pore types in the marine shale. It is derived from the process of organic matter accumulation and thermal evolution, and many tiny pores or fissures were developed due to changes in the geological environment. The organic matter is mainly distributed along the microlayer or the inter-deposited section, and it is easy to form a network of interconnected pores to improve the permeability. Many studies in North America have shown that TOC content has a good positive correlation with saturated adsorption $[39,40]$. The degree of 
development of organic nanopores is closely related to the maturity of the organic matter. It means that there are more pores in the organic matter with higher maturity. Additionally, the organic matter also affects the adsorption capacity of shale. Actually, the adsorption capacity follows as Type $\mathrm{II}_{2}>$ Type $\mathrm{II}_{1}>$ Type I [41]. Vitrinite and inertinite have microporous properties and a high internal surface area, which can provide a large number of adsorption points for methane [42]. Compared with the other set of shale series (Longmaxi Formation) in the same region (as shown in Table 4), the organic matter types are Type I, while the TOC and Ro of the Niutitang Formation shale are higher, showing better adsorption capacity and competitiveness.

Table 4. Comparison of the geological parameters of Niutitang Formation shale in northwestern Hunan with that of five main shale gas basins in the United States (Modified from [4,25,43]).

\begin{tabular}{|c|c|c|c|c|c|c|}
\hline Index & $\begin{array}{c}\text { Burial } \\
\text { Depth(m) }\end{array}$ & $\begin{array}{c}\text { Thickness } \\
\text { (m) }\end{array}$ & TOC (\%) & $R_{\mathrm{O}}(\%)$ & $\begin{array}{c}\text { Total Gas } \\
\text { Content }\left(\mathrm{m}^{3} / \mathrm{t}\right)\end{array}$ & Porosity $(\%)$ \\
\hline Locality & $100-4000$ * & $\geq 30 *$ & $\geq 1.2 *$ & $\geq 1.75 *$ & $\geq 1 *$ & $\geq 2 *$ \\
\hline Antrim & $200-800$ & 20 & $0.3-24.0$ & $0.4-0.6$ & $1.5-3.7$ & 9 \\
\hline Ohio & $670-1670$ & $100-330$ & $0-4.7$ & $0.4-1.3$ & $2.2-3.7$ & 4.7 \\
\hline New Albany & $200-1630$ & $33-133$ & $1.0-25.0$ & $0.4-1.0$ & $1.5-3.0$ & $10-14$ \\
\hline Barnett & $1980-2590$ & 76 & 4.5 & $1.0-2.1$ & $11.1-13.0$ & $4-5$ \\
\hline Lewis & 914-1829 & $152-579$ & $0.5-2.5$ & $1.6-1.9$ & $0.6-1.8$ & $3-5.5$ \\
\hline $\begin{array}{c}\text { Longmaxi } \\
\text { (northwestern Hunan) }\end{array}$ & $0-3300$ & 50-150 & $0.12-3.86$ & $1.0-4.3$ & 2.34 & 1.7 \\
\hline $\begin{array}{c}\text { Niutitang } \\
\text { (northwestern Hunan) }\end{array}$ & $0-1300$ & $70-110$ & $2.6-4.1$ & $2.7-3.5$ & $0.5-2.1$ & $3.2-7.5$ \\
\hline
\end{tabular}

* Data is adopted from $[4,25,43]$.

\subsubsection{Reservoir Capacity}

Shale is both the source rock and reservoir. Free gas and adsorbed gas coexist and are consisted of shale gas, and the storage types in the reservoir are various [44]. Micropores and micro-fractures are important storage spaces and circulation channels for free gas. The degree of development is directly related to the shale gas reserves and whether the reservoir has exploration and development of commercial values [20,45].

The pore space in the organic matter is an essential condition for the objective existence of the adsorbed gas. The pore surface provides adsorption points for the adsorbed gas. The specific surface area and the total pore volume are strongly positively correlated with saturated adsorption gas, while the average pore diameter is negatively correlated with it. The evolution of shale pores makes the internal structure of the fracture more complex. The dense seepage network is formed with the connection of each pore, which provides conditions for the microscopic migration and occurrence of shale gas. In addition, the organic matter which evolves to the end can provide large quantities of liquid hydrocarbons. The bubble-forming mechanism of liquid hydrocarbons forms a large number of nanopores that can become the main reservoir space for shale gas [46].

The porosity of the Niutitang Formation shale is above the average value compared with that of several major shale reservoirs in the United States (see Table 4). Figure 7 shows a statistical diagram of the pore size distribution with the DFT (Density Functional Theory) method (Sample \#11). More than $60 \%$ of the microscopic pores are nanopores inside the organic matter. The microscopic pores are mainly micro-mesopores, which provide the main pore volume and specific surface area for gas adsorption. The proportion of micropores is about $35.5 \%-72.3 \%$. Meanwhile, in the siliceous shale with high pyrite and quartz content, intergranular voids developed in the pyrite particles provide an effective space for gas storage. Quartz can improve the anti-compaction ability of shale, protect various nanopores formed by shale, improve the storage capacity of shale, and reduce the damage caused by compaction. All of these maximize the preservation of a large number of nanopores formed during shale evolution. 


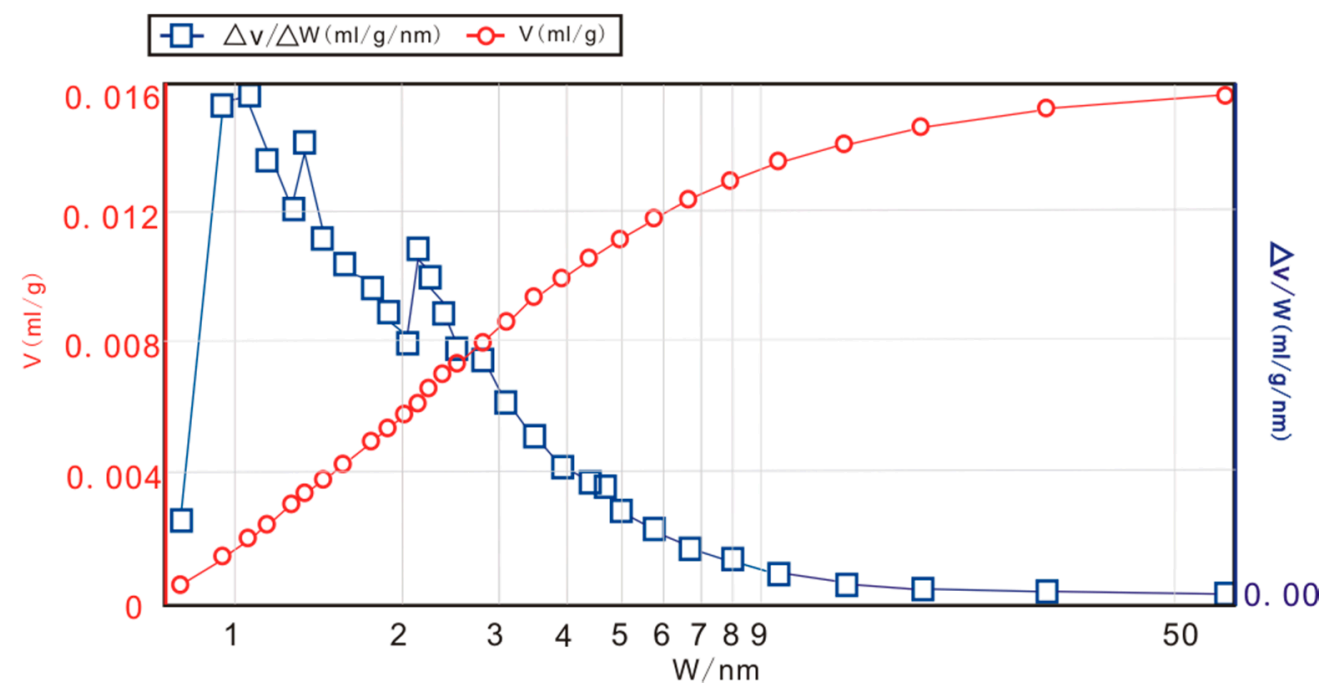

Figure 7. Statistical graph of aperture distribution (Sample \#11).

\subsection{Fracability}

\subsubsection{Uniaxial Compression Failure Modes}

The initiation of hydraulic fractures and the stress distribution of shale reservoirs are also affected by the uniaxial compression strength (UCS) of shale, while cracks begin to extend when the stress intensity reaches or exceeds the fracture toughness of the shale $[47,48]$. The more organic matter content in shale with a lower UCS, the easier for cracks to initiate and extend forward during fracturing [49].

The carbonaceous shale has a lower UCS due to higher TOC and clay mineral content (as shown in Figure 8a). The fracture is more likely to extend forward after initiation of fracturing, and the fracture surface is mostly a single shear plane (Figure 9a). The fracture is mostly scattered along the crack, and plane symmetry double-vane fractures or multiple fractures will be generated during fracturing.

The mechanical testing results indicated that the UCS of siliceous shale samples is obviously higher than that of carbonaceous shale, showing a higher brittleness. Moreover, the stress-strain curve has higher variability (Figure 8b), indicating poor homogeneity. In the uniaxial compression process, the failure mode appears as a small fragment fracturing and mostly a multi-shear surface failure (Figure 9b). This is because the siliceous shale has a higher degree of clay mineral transformation. The shale undergoes dissolution and recrystallization of quartz during the diagenesis process. The bedding and brittleness of the shale are obviously strengthened, resulting in a large number of natural structural cracks or weak interlayers filled with quartz and pyrite. The shale undergoes the dissolution and recrystallization of quartz during the diagenesis process, and the bedding and brittleness of the shale are obviously strengthened, resulting in a large number of natural structural cracks or weak interlayers filled with quartz and pyrite. Thus, the mechanical properties of the shale also have great changes correspondingly, which means that a large amount of non-planar shear cracks can be generated in the fracturing transformation, and the fracture seam is more likely to be generated. 


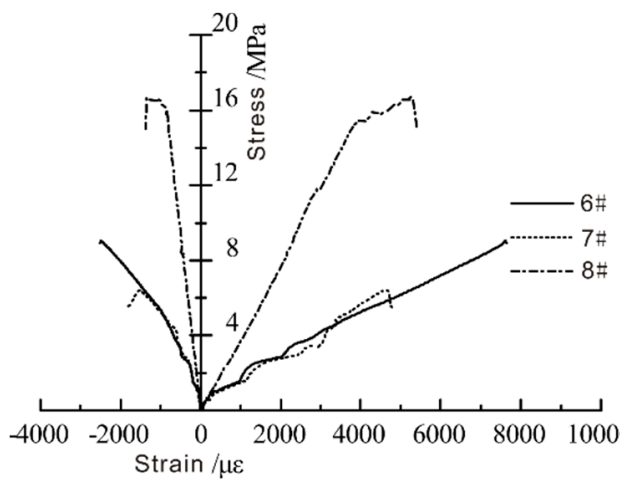

(a)

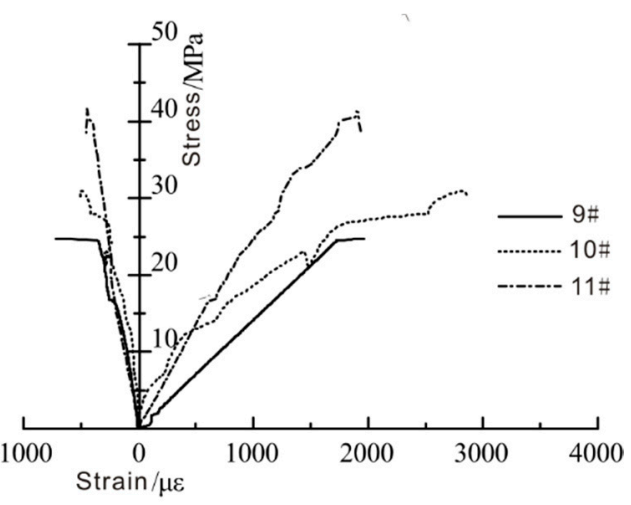

(b)

Figure 8. Stress-strain curve of marine shales under uniaxial compression test: (a) Carbonaceous shales at Changde; (b) Siliceous shales at Chande.

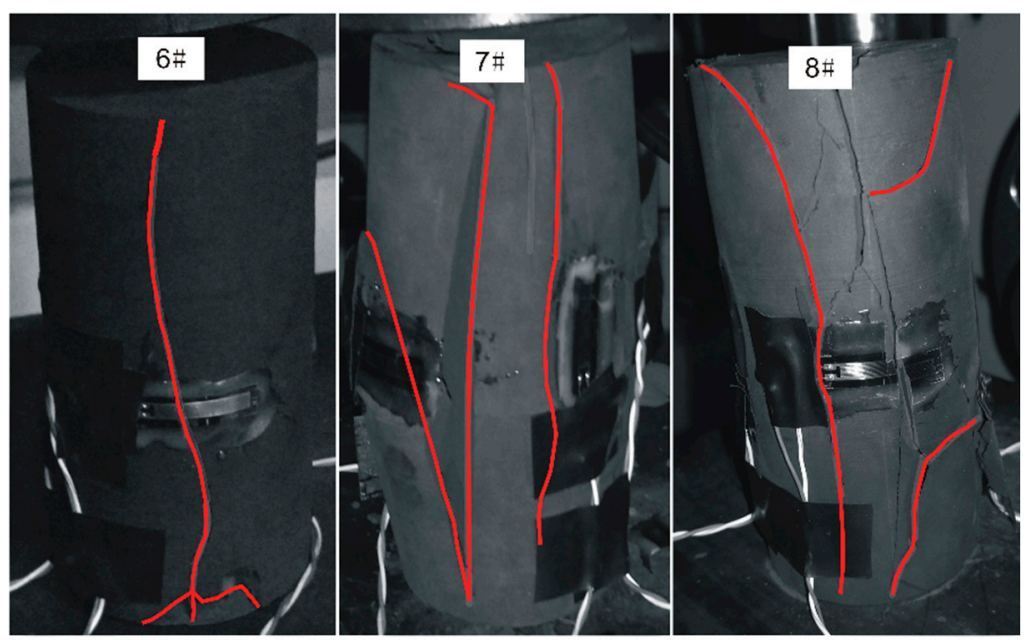

(a)

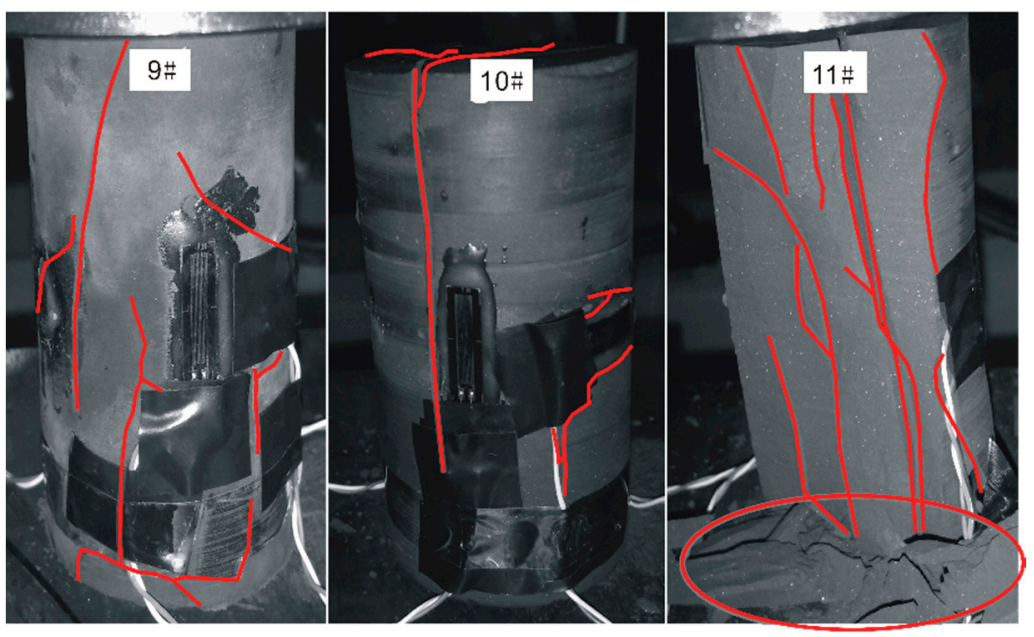

(b)

Figure 9. Failure modes of shale samples under uniaxial compression test: (a) Carbonaceous shales; (b) Siliceous shales.

\subsubsection{Brittleness Index}

The brittleness of shale is an important factor affecting its fracability. It is easy to form natural fissures and induced cracks under external forces when the brittle mineral content of shale is high [50]. 
The brittleness index is usually used to characterize the brittleness of rocks as this index can reflect the development and connection of fracture networks after reservoir fracturing [51]. Rickman et al. [32] concluded that the calculation of the brittleness index by the rock mechanics method can be derived via the data from the favorable area and its boundary rock formation. The brittleness index calculated by this method can more accurately reflect the fracability of the reservoir. Young's modulus and Poisson's ratio are the main parameters to evaluate the brittleness quantitatively. Figure 10 presents the ternary plot of the mineral content of Niutitang Formation shale. As can be seen, the dominated mineral components, such as quartz, feldspar, pyrite, and clay, are distributed in the shale. The distribution of heterogeneous minerals and a large number of brittle minerals will result in a high Young's modulus and a low Poisson's ratio, which presents the characteristics of the high brittleness.

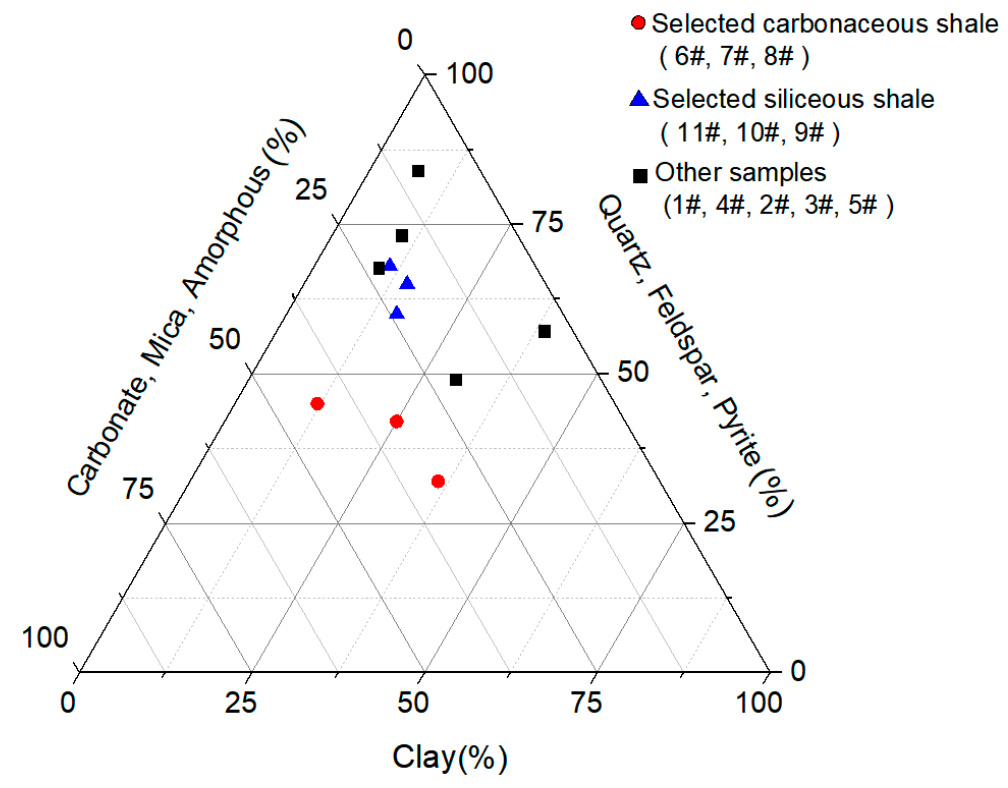

Figure 10. Ternary plot of the mineral content of Niutitang Formation shale in northwestern Hunan.

Based on the formula of Rickman, the brittleness index of the Niutitang Formation shale in northwestern Hunan was calculated. As shown in Table 5, the brittleness index of the Niutitang Formation carbonaceous shale in northwestern Hunan ranges from $0.20-0.37$, which is lower than that of the Niutitang Formation siliceous shale (0.42-0.78) and also lower than that of Barnett shale in the United States (0.50-0.83). By comprehensively considering the content of brittle mineral, mechanical parameters, and brittleness index, it can be seen that the fracability of the Niutitang Formation shale in northwestern Hunan is comparable to that of the Barnett shale.

Table 5. Comparison of the minerals and mechanical parameters of Barnett shale with that of the marine shale in Niutitang Formation in northwestern Hunan. (Modified from [52]).

\begin{tabular}{ccccccc}
\hline Area & Clay\% & Quartz\% & Feldspar\% & $\begin{array}{c}\text { Poisson } \\
\text { Ratio }\end{array}$ & $\begin{array}{c}\text { Young's } \\
\text { Modulus (GPa) }\end{array}$ & $\begin{array}{c}\text { Average } \\
\text { Brittleness Index }\end{array}$ \\
\hline Siliceous shale (Barnett) & 27 & $35-50$ & 7 & $0.2 ~ 0.3$ & 33.0 & 0.67 \\
Siliceous shale (9\#-11\#) & $12-26$ & $28-42$ & $15-16$ & $0.15 \sim 0.29$ & $14.15-25.60$ & 0.63 \\
Carbonaceous shale (6\#-8\#) & $12-36$ & $19-27$ & $5-16$ & $0.19-0.24$ & $1.25-3.86$ & 0.29 \\
\hline
\end{tabular}

\subsubsection{Natural Fractures}

Natural fractures are the main breakthrough point for the shale hydraulic fracturing to form more abundant fracture networks. They can reduce the initiation pressure of shale during hydraulic fracturing, and enlarge the flow interface between the fracture and non-fracture zone, then connect the fractures and pores [53,54]. A large number of open, natural cracks in shale can increase the 
local permeability. Bowker [11] concluded that the natural fractures are the main contributor to the weak link of shale fracturing mechanics by studying the Barnett shale. There are many natural fractures with a small width and a low filling degree in the carbonaceous shale. These fractures include structural tensile shear fissures (few branches and long length, as shown in Figure 11, Sample 7\#) and non-structural shrinkage fractures (rough bending and irregular development, as shown in Figure 11, Sample 6\#). In addition, some of the filling strip-like dissolution pores (as shown in Figure 11, Sample $8 \#)$ are developed and filled with mud and calcite. The maximum width of the pores ranges from $0.5 \mathrm{~mm}$ to $1 \mathrm{~mm}$. Different from the carbonaceous shale, the siliceous shale develops a large number of natural structural fractures filled with quartz and pyrite, including shear fractures and tensile shear fractures. Some shear fractures have a high degree of quartz filling (smooth plane, long extension, and few branches, as shown in Figure 11, Sample 10\#), and others are filled with quartz and pyrite (a conjugate $\mathrm{X}$ type, as shown in Figure 11, Sample 12\#). The tensile shear fractures show multiple fractures combinations (Figure 11, Sample 11\#), and tiny fissures near the main fractures. To sum up, the development of fractures in the Niutitang Formation shales in northwestern Hunan is high.

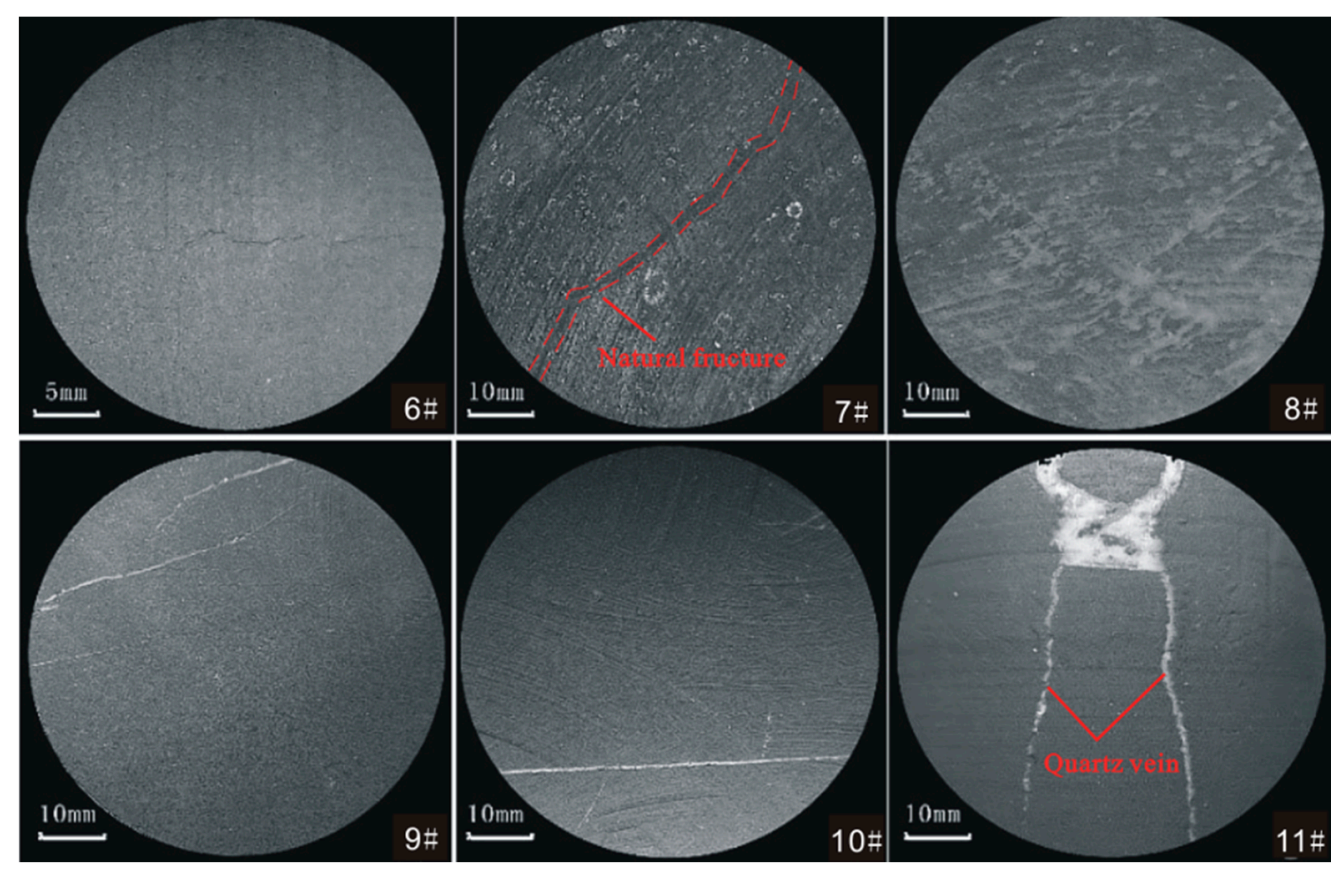

Figure 11. Morphology of shales intrinsic fractures: (6\#-8\#) carbonaceous shales; (9\#-11\#) siliceous shales.

\subsection{The Recommendation of a Comprehensive Framework for Exploitation Potential}

In order to better investigate the difference between proven reserves and production for reflecting the effective exploitation potential to meet commercial exploitation standards, in this section we recommend using a comprehensive framework to evaluate the effective exploitation potential of shale reservoirs.

Figure 12 presents the framework of a comprehensive evaluation for exploitation potential. This framework was built involving both accumulation conditions and the shale fracability. From the framework, it can be seen that the adsorption capability and reservoir capability are the main factors influencing accumulation conditions. In terms of the accumulation condition, on one hand, the adsorption capability depends on Kerogen types, clay mineral, matrix pore, Pyrite, and TOC; on the other hand, Quartz, Pyrite, and the matrix pore contribute more to the reservoir capability. Moreover, the development of the matrix pore is closely related to TOC, Ro, and minerals. For the shale fracability, due to the fact that the brittle minerals and porosity are determined by accumulation conditions, the fracability depends on the failure mode, brittleness index, and microstructure. Therefore, further 
research needs to establish a reliable relationship between the geological condition and mechanical behavior related to accumulation conditions and the shale fracability to quantitavely optimize the parameters for the exploitation.

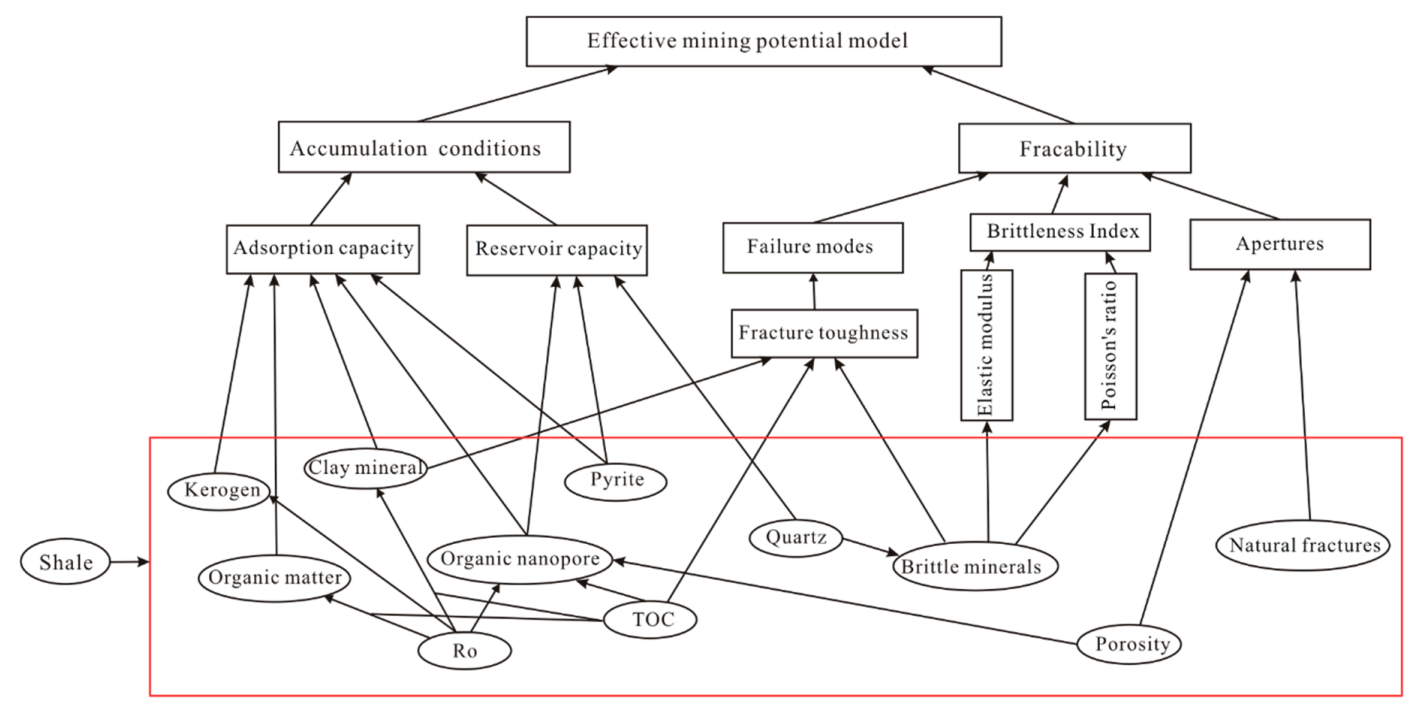

Figure 12. The framework for evaluating effective exploitation potential of a shale gas reservoir.

Taking the Niutitang Formation shale in northwestern Hunan as an example to be evaluated within this framework, it is concluded that the Niutitang Formation shale in northwestern Hunan shows superior accumulation conditions compared with North American shale basins. Additionally, the fracability behaviors show that the brittleness and microstructure development are comparable to those of the Barnett shale. Thus, the Niutitang Formation shale in northwestern Hunan is characterized by good gas-bearing properties, and high effective shale-gas exploitation potential in this reservoir can be determined considering both accumulation conditions and fracability.

\section{Conclusions}

To allow proven reserves to reflect the accurate production for shale gas exploitation, this paper investigates the effective exploitation potential of shale gas considering both accumulation conditions and shale fracability. Based on this, a comprehensive evaluation framework is recommended. In this study, the effective exploitation potential of Niutitang Formation shale in northwestern Hunan was evaluated via both field data and laboratory tests.

For accumulation conditions, the geochemical analysis indicated that the Niutitang Formation shale in northwestern Hunan is characterized by high organic matter abundance (TOC range from $2.60 \%$ to $4.10 \%$ ), high thermal evolution (Ro between $2.7 \%$ and $3.6 \%$ ), high pyrite contents $(8.1 \% \sim 27.3 \%$ ), and highly developed micropores (porosity range from $3.24 \%$ to $7.47 \%$ ), all of which favor the generation, adsorption, and accumulation of shale gas. It has favorable accumulation conditions for forming shale gas reservoirs.

As for the shale fracability, the natural fractures of the marine shale in the Niutitang Formation are highly developed, and the internal pores are mainly micropore and mesopore (micropore proportion range from $35.5 \%$ to $72.3 \%$, average pore diameter range from $3.02 \mathrm{~nm}$ to $14.24 \mathrm{~nm}$ ), which can effectively improve the space for fracture transformation and connection. The uniaxial compression failure modes are mainly characterized by the scattering of the single shear plane and the cracking of multiple shear planes, which are consistent with the organic matter types and brittle mineral content. The brittleness index of Niutitang Formation shale (average value 0.63 ) is comparable to that of Barnett shale (average value 0.67). 
Comparing the five validated shale gas exploitation regions in the United States, the key indicators of accumulations and shale fracability are comparable, indicating that Niutitang Formation shale in northwestern Hunan has high effective exploitation potential that can meet the commercial exploitation standards because of advantages in accumulation condition combining with favorable fracability for enhancing hydraulic fracturing.

Author Contributions: H.C. proposed this topic and supervised the work; author T.W. mainly carried out and completed this work; author T.B. provided and analyzed the field data; author P.S. and others supplemented and perfected this work in the later stage; all authors read and approved the final manuscript.

Funding: This research was funded by "National Natural Science Foundation of China, grant number 41302124" and the APC was funded by "Open Funding by Key Laboratory of Oil and Gas Reservoir Geology and Exploitation, grant number PLN201607".

Acknowledgments: The work presented in this paper was financially supported by the National Natural Science Foundation of China (Grant No. 41302124), Open Funding by Key Laboratory of Oil and Gas Reservoir Geology and Exploitation (Grant No. PLN201607), and the Independent Innovation Project of Central South University (Grant No. 2018zzts700). We are also grateful to all the editors and reviewers for their invaluable comments.

Conflicts of Interest: The authors declare no conflict of interest.

\section{References}

1. Curtis, M.; Ambrose, R.; Sondergeld, C. Structural Characterization of Gas Shales on the Micro and Nano-Scales. In Proceedings of the Canadian Unconventional Resources and International Petroleum Conference, Calgary, AB, Canada, 19-21 October 2010.

2. Kale, S.; Rai, C.; Sondergeld, C. Petrophysical Characterization of Barnett Shale. In Proceedings of the SPE Unconventional Gas Conference, Pittsburgh, PA, USA, 23-25 February 2010.

3. EIA. International Energy Outlook; EIA: Washington, DC, USA, 2018.

4. Curtis, J.B. Fractured shale-gas systems. AAPG Bull. 2002, 86, 1921-1938.

5. Klett, T.R.; Charpentier, R.R. FORSPAN Model Users Guide; Center for Integrated Data Analytics Wisconsin Science Center: Reston, VA, USA, 2003.

6. Ewing, J.; Jackson, G. Barnett Shale Creates Win-Win Situation for Homeowners and Energy Companies; Fort Worth Business Press: Fort Worth, TX, USA, 2005; Volume 18, p. 28.

7. Hill, R.J. Modeling of gas generation from the Barnett Shale, Fort Worth Basin, Texas. AAPG Bull. 2007, 91, 501-521. [CrossRef]

8. Burnaman, M.D.; Shelton, J. Shale Gas Play Screening and Evaluatiosn Criteria. China Pet. Explor. 2009, 14, 51-64.

9. Editorial Committee of Shale Gas Geology and Exploration Practice Series. New Progress in Shale Gas Exploration and Development in North America; Petroleum Industry Press: Beijing, China, 2009. (In Chinese)

10. Macquaker, J.; Davies, S. Lithofacies Variability in Fine-Grained Mixed Clastic Carbonate Successions: Implications for Identifying Shale-Gas Reservoirs. In Proceedings of the AAPG Annual Meeting, San Antonio, TX, USA, 20-23 April 2008.

11. Bowker, K.A. Barnett Shale gas production, Fort Worth Basin: Issues and discussion. AAPG Bull. 2007, 91, 523-533. [CrossRef]

12. ANON. Marcellus Shale-Appalachian Basin Natural Gas Play [EB/OL]. Available online: http:/ /geology. com/articles/marcellusshale.shtml (accessed on 2 December 2018).

13. He, J.L.; Wang, J.; Yu, Q. Pore structure of shale and its effects on gas storage and transmission capacity in well HD-1 eastern Sichuan Basin, China. Fuel 2018, 226, 709-720. [CrossRef]

14. Yang, R.; He, S.; Hu, Q.H. Pore characterization and methane sorption capacity of over-mature organic-rich Wufeng and Longmaxi shales in the southeast Sichuan Basin, China. Mar. Pet. Geol. 2016, 77, 247-261. [CrossRef]

15. Yong, T.; Fan, Y.; Lv, Q.Q. Analysis of the Tectonic Stress Field of SE Sichuan and its Impact on the Preservation of Shale Gas in Lower Silurian Longmaxi Formation of the Dingshan Region, China. J. Geol. Soc. India 2018, 92, 92-100. [CrossRef]

16. Li, S.R.; Zeng, L.; Wang, Z.P. A New Insight into Shale-Gas Accumulation Conditions and Favorable Areas of the Xinkailing Formation in the Wuning Area, North-West Jiangxi, China. Energies 2018, 11, 12. [CrossRef] 
17. Wang, R.; Sang, S.; Zhu, D. Pore characteristics and controlling factors of the Lower Cambrian Hetang Formation shale in Northeast Jiangxi, China. Energy Explor. Exploit. 2017, 36, 43-65. [CrossRef]

18. Zhang, L.T.; Guo, J.H.; Jiao, P. Accumulation conditions and resource potential of shale gas in Lower Cambrian Niutitang Formation, northwestern Hunan. J. Cent. South Univ. (Sci. Technol.) 2014, 45, 1163-1173.

19. Lin, T.; Zhang, J.C.; Li, B. Shale gas accumulation conditions and gas-bearing properties of the Lower Cambrian Niutitang Formation in Well Changye 1, northwestern Hunan. Acta Pet. Sin. 2014, 35, 839-846.

20. Zhou, Q.H.; Song, N.; Wang, C.Z. Characteristics of shale and gas content of Niutitang Formation in Changde region of Hunan Province. Nat. Gas Geosci. 2015, 26, 301-311.

21. Wang, Y.; Zhu, Y.M.; Chen, S.B. Formation conditions of shale gas in Lower Cambrian Niutitang Formation, northwestern Hunan. J. China Univ. Min. Technol. 2013, 42, 586-594.

22. Jiang, W.; Tang, S.H.; Gong, Y.H. The Reservoir Characteristics and Favorable Areas of Shale Gas in Northwestern Hunan Lower Cambrian Niutitang. J. Southwest Pet. Univ. (Sci. Technol. Ed.) 2014, 36, $16-24$.

23. Xiao, Z.H.; Yang, R.F.; Feng, T. Reservoir-forming conditions and exploration potential of shale gas in Lower Cambrian Niutitang Formation, Northwestern Hunan. J. Hunan Univ. Sci. Technol. (Nat. Sci. Ed.) 2012, 27, 50-53.

24. Wu, J.J.; Zhang, S.H.; Cao, H. Fracability evaluation of shale gas reservoir-A case study in the Lower Cambrian Niutitang Formation, northwestern Hunan, China. J. Pet. Sci. Eng. 2018, 164, 675-684. [CrossRef]

25. Wan, Y.; Tang, S.H.; Pan, Z.J. Evaluation of the shale gas potential of the lower Silurian Longmaxi Formation in northwest Hunan Province, China. Mar. Pet. Geol. 2017, 79, 159-175. [CrossRef]

26. Hou, B.; Chen, M.; Li, Z.M. Propagation area evaluation of hydraulic fracture networks in shale gas reservoirs. Pet. Explor. Dev. 2014, 41, 763-768. [CrossRef]

27. Jin, X.C.; Shah, S.N.; Roegiers, J.C. An Integrated Petrophysics and Geomechanics Approach for Fracability Evaluation in Shale Reservoirs. SPE J. 2015, 20, 518-526. [CrossRef]

28. Jin, X.C. An integrated geomechanics and petrophysics study of hydraulic fracturing in naturally fractured reservoirs. Ph.D. Thesis, The University of Oklahoma, Norman, Oklahoma, 2014.

29. Perez, A.R. Brittleness estimation from seismic measurements in unconventional reservoirs: Application to the Barnett shale. SEG Tech. Progr. Expand. 2013, 2258-2262. [CrossRef]

30. Feng, A.F.; Zhang, Y.J. Application of image J software for image processing and fabric porosity analyzing. Knitt. Ind. 2015, 1, 9-11.

31. Enderlin, M.B.; Alsleben, H.; Breyer, J.A. Predicting fracability in shale reservoirs. In Proceedings of the AAPG Hedberg Conference, Napa, CA, USA, 14-18 March 2011; pp. 1-4.

32. Rickman, R.; Mullen, M.J.; Petre, J.E. A Practical Use of Shale Petrophysics for Stimulation Design Optimization: All Shale Plays Are Not Clones of the Barnett Shale. In Proceedings of the SPE Technical Conference and Exhibition, Denver, CO, USA, 21-24 September 2008.

33. Pu, B.L.; Jiang, Y.L.; Wang, Y. Reservoir-forming conditions and favorable exploration zones of shale gas in Lower Silurian Longmaxi Formation of Sichuan Basin. Acta Pet. Sin. 2010, 31, 225-230.

34. Wang, G.K.; Jiao, P. Accumulation Condition of Niutitang Formation of Lower Cambrian Shale Gas Resource in Northwestern Hunan Region. Energy and Energy Conserv. 2013, 1, 35-51.

35. Yan, J.P.; Yan, Y.; Sima, L.Q. Relationship between fracture characteristics and "five-property" of shale reservoir. Lithol. Reserv. 2015, 27, 87-93.

36. Han, X.X.; Jiang, X.M.; Wang, D.Z. Effect of combustion process on pore structure of oil shale ash. J. Chem. Ind. Eng. (China) 2007, 58, 1296-1300.

37. Gao, Z.Y.; Yang, S.; Jiang, Z.X. Investigating the spontaneous imbibition characteristics of continental Jurassic Ziliujing Formation shale from the northeastern Sichuan Basin and correlations to pore structure and composition. Mar. Pet. Geol. 2018, 98, 697-705. [CrossRef]

38. Liu, C.L.; Dong, Y.X.; Che, P. Pyrite Formation and Its Controls in Black Shales of the Buxin Formation (Lower Eocene) from the Sanshui Basin, Guangdong. Acta Sedimentol. Sin. 2006, 24, 75-80.

39. Hickey, J.J.; Bo, H. Lithofacies summary of the Mississippian Barnett Shale, Mitchell 2 T.P. Sims well, Wise County, Texas. AAPG Bull. 2007, 91, 437-443. [CrossRef]

40. Ross, D.J.K.; Bustin, R.M. Sediment geochemistry of the Lower Jurassic Gordondale Member, northeastern British Columbia. Bull. Can. Pet. Geol. 2006, 54, 337-365. [CrossRef] 
41. Chen, K.; Zhang, J.C.; Tang, X. Main controlling factors on shale adsorption capacity of the Lower Silurian Longmaxi Formation in western Hunan-Hubei area. Oil Gas Geol. 2016, 37, 23-29.

42. Chalmers, G.R.L.; Bustin, R.M. The organic matter distribution and methane capacity of the Lower Cretaceous strata of Northeastern British Columbia, Canada. Int. J. Coal Geol. 2007, 70, 223-239. [CrossRef]

43. Zhao, J.B.; Tang, S.H.; Zhang, S.H. Analysis on Characteristics and Influence Factors of Shale Pore in Niutitang Formation of Northwestern Hunan. Coal Sci. Technol. 2014, S1, 261-265.

44. Li, Y.W.; Zuo, L.H.; Yu, W. A Fully Three Dimensional Semianalytical Model for Shale Gas Reservoirs with Hydraulic Fractures. Energies 2018, 11, 436. [CrossRef]

45. Javadpour, F.; Fisher, D.; Unsworth, M. Nanoscale Gas Flow in Shale Gas Sediments. J. Can. Pet. Technol. 2007, 46, 55-61. [CrossRef]

46. Liu, H.L.; Wang, Y.M.; Liu, X.N. Nanopore characteristics of Longmaxi Formation and forming mechanism of bubble to pore in marine shale of Sichuan Basin. Nat. Gas Ind. 2017, 37, 11-16.

47. Liang, L.X.; He, S.P.; Zhang, A.D. Test of shale type I fracture toughness by CCNBD specimen. West-China Explor. Eng. 2016, 11, 41-43. (In Chinese)

48. Liu, J.; Wang, J.G.; Leung, C.F. A Multi-Parameter Optimization Model for the Evaluation of Shale Gas Recovery Enhancement. Energies 2018, 11, 654. [CrossRef]

49. Chen, J.G.; Deng, J.G.; Yuan, J.L. Determination of fracture toughness of modes I and II of shale formation. Chin. J. Rock Mech. Eng. 2015, 6, 1101-1105.

50. Zou, C.N.; Dong, D.Z.; Wang, S.J. Geological characteristics, formation mechanism and resource potential of shale gas in China. Pet. Explor. Dev. 2010, 37, 641-653. [CrossRef]

51. Kahraman, S.; Altindag, R. A brittleness index to estimate fracture toughness. Int. J. Rock Mech. Min. Sci. 2004, 41, 343-348. [CrossRef]

52. Ding, W.L.; Li, C.; Li, C.Y. Dominant factor of fracture development in shale and its relationship to gas accumulation. Earth Sci. Front. 2012, 19, 212-220.

53. Tang, Y.; Xing, Y.; Li, L.Z. Influence factors and evolution methods of the gas shale fracability. Earth Sci. Front. 2012, 19, 356-363.

54. Ma, C.F.; Elsworth, D.; Dong, C.M. Controls of hydrocarbon generation on the development of expulsion fractures in organic-rich shale: Based on the Paleogene Shahejie Formation in the Jiyang Depression, Bohai Bay Basin, East China. Mar. Pet. Geol. 2017, 86, 1406-1414. [CrossRef] 